\title{
Agronomic performance of arabica coffee genotypes in northwest Rio de Janeiro State
}

\author{
W.P. Rodrigues ${ }^{1}$, H.D. Vieira ${ }^{1}$, D.H.S.G. Barbosa ${ }^{2}$, G.R. Sousa Filho ${ }^{1}$ and \\ F.L. Partelli ${ }^{3}$
}

${ }^{1}$ Universidade Estadual do Norte Fluminense Darcy Ribeiro, Laboratório de Fitotecnia, Parque Califórnia, Campos dos Goytacazes, RJ, Brasil ${ }^{2}$ Embrapa Mandioca e Fruticultura, Núcleo de Recursos Genéticos e Desenvolvimento de Variedades, Cruz das almas, BA, Brasil ${ }^{3}$ Universidade Federal do Espírito Santo, Bairro Litorâneo, São Mateus, ES, Brasil

Corresponding author: W.P. Rodrigues E-mail: wevertonuenf@hotmail.com

Genet. Mol. Res. 13 (3): 5664-5673 (2014)

Received February 4, 2014

Accepted April 4, 2014

Published July 25, 2014

DOI http://dx.doi.org/10.4238/2014.July.25.22

\begin{abstract}
Considering the productive potential of arabica coffee in the Rio de Janeiro State and the shortage of breeding programs for this species in the state, this study aimed to evaluate the vegetative and productive characteristics of 25 arabica coffee genotypes to indicate 1 or more varieties for the northwest Rio de Janeiro region. The experiment was in Varre e Sai, RJ, Brazil, and plants were planted in 2007 with a spacing of $2.5 \times 0.8 \mathrm{~m}$. Five plots were used, consisting of 8 plants per plot to measure vegetative growth, height, stem diameter, and plagiotropic branch number characteristics and productivity in the biennia 2009/2010 and 2011/2012. The classification by sieve was performed at harvest in 2011. The variables were subjected to analysis of variance and means grouped by the Scott Knott test at $5 \%$ probability, and the productivity was subjected to joint analysis of variance. Pearson's correlation coefficients between growth and productivity
\end{abstract}


variables were estimated. The best genotypes were Catucaí Amarelo 2 SL, Catiguá MG 02, Acauã, Palma II, Sabiá 398, IPR 103, IPR 100, Catucaí Amarelo 24/137, and Catucaí Amarelo 20/15.

Key words: Coffea arabica; Productivity; Physical quality; Growth

\section{INTRODUCTION}

The genus Coffea includes at least 124 species; of these, Coffea arabica and C. canephora are economically relevant (Davis et al., 2011). In recent years, coffee production in developing countries has yielded approximately 144 million $60-\mathrm{kg}$ bags of processed coffee, and Brazil, as the largest producer and exporter, produced approximately 51 million bags (International Coffee Organization, 2014).

Rio de Janeiro State, which was once the largest national producer, only occupied the seventh ranking in the 2013 harvest, producing approximately 281,000 benefited bags of arabica coffee (C. arabica L.) in an area of 13.276 ha (Conab, 2014). Therefore, there are several areas with potential favorable conditions for the cultivation of $C$. arabica.

In addition to phytosanitary problems such as rust leaf (Hemileia vastatrix Berk et $\mathrm{Br}$ ) and root-knot nematode (Meloidogyne exigua Goeldi, 1887) and the maintenance of old depleted fields (Barbosa et al., 2004, 2010), the absence of technologies such as adequate fertilization (Barbosa et al., 2006) and lack of improved cultivars contributed to the decay of the culture in the state (Conab, 2014). The breeding programs have developed varieties of coffee to increase productivity, aggregated agronomic traits for resistance to pests and diseases, developed plants of short height and adapted to local climate and soil conditions (Petek et al., 2006), and developed plants with desirable fruit characteristics. However, the coffee regions have different climatic conditions, and the cultivar responses differ in different environments because of genotype-environment interactions (Cucolotto et al., 2007; Pinto et al., 2012). Thus, despite the large number of available cultivars, we do not know which of these materials to use in different coffee growing regions of the country, including northwest Rio de Janeiro State. This lack of information contributes to a slow process using new cultivars (Carvalho et al., 2012).

Regional studies, such as those performed by Paiva et al. (2010) and Carvalho et al. (2012), are an important tool to determine the viability of new cultivars to minimize future risks that may cause losses to producers. Considering the productive potential of $C$. arabica in Rio de Janeiro State and the shortage of breeding programs for this species in the state, this study aimed to evaluate the vegetative and productive characteristics of 25 arabica coffee genotypes to indicate 1 or more cultivars for use in northwest Rio de Janeiro State.

\section{MATERIAL AND METHODS}

The experiment was installed in 2007 at Panorama Farm 1 in Varre e Sai, Rio de Janeiro, Brazil, on oxisol at $-20^{\circ} 56^{\prime} 10^{\prime \prime}$ latitude and $-41^{\circ} 54^{\prime} 43^{\prime \prime}$ longitude at an altitude of $780 \mathrm{~m}$. It is a typical tropical climate with cool summers, colder winters, an average annual temperature of $19.0^{\circ} \mathrm{C}$, and average annual rainfall of $1601 \mathrm{~mm}$. The seeds of the genotypes that were used in the experiment (Table 1) were acquired from Empresa de Pesquisa Agropecuária de Minas Gerais. 
Table 1. Summary of analysis of variance and variation coefficients for plant height, stem diameter, plagiotropic branch number, average biennium productivity, grains retained on sieve size 16 , moca beans, and joint analysis of the productivity of 2009/2010 and 2011/2012 biennia of 25 arabica coffee genotypes in northwestern Rio de Janeiro State, Brazil.

\begin{tabular}{|c|c|c|c|c|c|}
\hline \multirow[b]{2}{*}{ Source of variation } & \multicolumn{5}{|c|}{ MS } \\
\hline & d.f. & Plant height (cm) & Stem diameter $(\mathrm{mm})$ & No. of plagiotropic branches & Average biennia \\
\hline Block & 4 & 342.83 & 167.45 & 119.90 & 6909.77 \\
\hline Genotype & 24 & $36754.19 * *$ & $3188.03 * *$ & $8632.60 * *$ & $22048.97 * *$ \\
\hline Residue & 96 & 7075.97 & 1623.23 & 40.12 & 204.74 \\
\hline CV $(\%)$ & & 4.20 & 8.12 & 7.86 & 17.46 \\
\hline Overall average & & 204.99 & 50.58 & 80.58 & 81.95 \\
\hline Source of variation & d.f. & Sieve size $16(\%)$ & Moca $(\%)$ & - & - \\
\hline Block & 2 & 38.59 & 70.64 & & \\
\hline Genotype & 24 & $2210.85^{* *}$ & $11317.81 * *$ & - & - \\
\hline Residue & 48 & 398.74 & 1736.03 & - & - \\
\hline CV $(\%)$ & & 16.55 & 8.66 & - & - \\
\hline Overall average & & 17.41 & 69.44 & - & - \\
\hline Source of variation & d.f. & Productivity (bag/ha) & - & - & - \\
\hline Block & 4 & 13820.65 & & & \\
\hline Genotype & 24 & $44097.64 *$ & - & - & - \\
\hline Residue & 96 & 39314.05 & - & - & - \\
\hline Biennium & 1 & 493.42 & - & - & - \\
\hline Genotype $\mathrm{x}$ Biennium & 24 & $10703.72 *$ & - & - & - \\
\hline Residue & 100 & 281.82 & - & - & - \\
\hline CV $(\%)$ & & 13.71 & - & - & - \\
\hline Overall average & & 81.95 & - & - & - \\
\hline
\end{tabular}

d.f. $=$ degrees of freedom; $* * *$ significant at 1 and $5 \%$ probability, respectively.

For the formation of seedlings, $11 \times 22 \mathrm{~cm}$ polyethylene bags and substrate were used. Crop management was performed according to specific literature. Assessments of vegetative development were made before harvests using a graduated scale to measure height, a Starrett ${ }^{\mathbb{B}}$ digital caliper to measure the stem diameter at the ground level, and counting of the plagiotropic branches. The productivity of the 2009/2010 biennium concerning the harvest totals for 2009 and 2010 and the 2011/2012 biennium concerning the harvest totals for 2011 and 2012 were evaluated, totaling 4 harvests, between May and July. The volume of harvested coffee cherries was transformed to benefit bags/ha using the scale of $480 \mathrm{~L}$ coffee cherries per $60-\mathrm{kg}$ sack (Carvalho et al., 2009). The 25 genotypes were evaluated using a spacing of $2.5 \times 0.8 \mathrm{~m}$ with random blocks and 5 plots with 8 plants per plot. For productivity, we used the split-plot array in time.

The classification was performed by sieve in samples obtained from the 2011 harvest with 3 replicates per genotype. The coffee was harvested and taken to the Panorama Farm 1 processing unit, where washing and separation of green coffee, cherry, and "boia" proceeded. The coffee cherries were peeled and pulped, and $1 \mathrm{~L}$ was removed and sent to the laboratory, where it was subjected to drying in a $45^{\circ} \mathrm{C}$ oven until the moisture content reached about $12 \%$. After reaching the moisture content, $200 \mathrm{~g}$ of each sample was removed for classification. For this classification, $100 \mathrm{~g}$ coffee beans from each sample, which was free of defects, was placed on the sieves (Brasil, 2003). After passing through the sieves, beans were classified as flat grains (retained on sieve 16) and moca beans (retained on sieve 11), and the volume contained in the sieve was weighed and expressed as a percentage.

Vegetative variables were subjected to analysis of variance, and means were com- 
pared with the Scott Knott test at 5\% probability. For productivity, a joint analysis of variance subdivided in time was performed with the plots representing the treatments and the subplots representing the set of 2 crops (biennium). Pearson's correlation coefficients between the growth and productivity variables were also estimated. All analyses were performed using the statistical analysis program Genes (Cruz, 2013).

\section{RESULTS AND DISCUSSION}

There were significant differences for vegetative variables and physical qualities of grains. Regarding productivity, there was a significant effect from the genotype and genotype $\mathrm{x}$ biennium interaction (Table 1).

For variable plant height, 5 groups were distinguished. Bourbon Amarelo had the highest average (Table 2), which was expected because it is tall type cultivar (Carvalho et al., 2008). Reducing the plant height, which would allow an increased density, mechanical harvesting, and would facilitate phytosanitary treatments, especially for leaf rust, is a relevant goal in breeding programs (Petek et al., 2008). Four groups were distinguished according to stem diameter. Bourbon Amarelo and Catiguá MG 01stood out among the genotypes (Table 2). Regarding the number of plagiotropic branches, 5 groups were distinguished, and Catiguá MG 01 stood out.

\begin{tabular}{|c|c|c|c|}
\hline Genotype & Plant height $(\mathrm{cm})$ & Stem diameter $(\mathrm{mm})$ & No. of plagiotropic branches \\
\hline 1-Catucaí Vermelho 785/15 & $213.60^{c}$ & $53.90^{\mathrm{c}}$ & $76.40^{\mathrm{d}}$ \\
\hline 2-Catucaí Amarelo $2 \mathrm{SL}$ & $240.40^{\mathrm{b}}$ & $51.64^{\mathrm{c}}$ & $72.10^{\mathrm{d}}$ \\
\hline 3-IPR & $195.20^{\mathrm{e}}$ & $47.88^{\mathrm{d}}$ & $77.40^{\mathrm{d}}$ \\
\hline 4-Catiguá MG 02 & $219.40^{c}$ & $56.86^{\mathrm{b}}$ & $81.58^{\mathrm{c}}$ \\
\hline 5-IPR 99 & $186.40^{\mathrm{e}}$ & $49.86^{\mathrm{c}}$ & $78.00^{\mathrm{d}}$ \\
\hline 6-Acauã & $201.00^{\mathrm{d}}$ & $50.86^{\mathrm{c}}$ & $85.20^{\mathrm{c}}$ \\
\hline 7-Araponga MG 01 & $205.60^{\mathrm{d}}$ & $48.42^{\mathrm{d}}$ & $82.00^{\mathrm{c}}$ \\
\hline 8-Palma II & $210.60^{\mathrm{d}}$ & $45.92^{\mathrm{d}}$ & $80.40^{c}$ \\
\hline 9-Sabiá 398 & $184.60^{\mathrm{e}}$ & $49.44^{\mathrm{c}}$ & $85.20^{\mathrm{c}}$ \\
\hline 10-IPR 103 & $197.40^{\mathrm{e}}$ & $51.48^{\mathrm{c}}$ & $86.40^{\mathrm{c}}$ \\
\hline 11-IPR 100 & $205.80^{\mathrm{d}}$ & $49.34^{\mathrm{c}}$ & $86.80^{\mathrm{c}}$ \\
\hline 12-H-4193-3-3-716-4-1 & $206.20^{\mathrm{d}}$ & $47.44^{\mathrm{d}}$ & $75.80^{\mathrm{d}}$ \\
\hline $13-\mathrm{H}-419-10-6-2-12-1$ & $194.00^{\mathrm{e}}$ & $44.90^{\mathrm{d}}$ & $84.40^{\mathrm{c}}$ \\
\hline 14-Catucaí Amarelo 24/137 & $223.80^{c}$ & $49.54^{c}$ & $92.00^{\mathrm{b}}$ \\
\hline 15-Iapar 59 & $185.00^{\mathrm{e}}$ & $52.94^{\mathrm{c}}$ & $76.60^{\mathrm{d}}$ \\
\hline 16-Oeiras & $194.60^{\mathrm{e}}$ & $45.86^{\mathrm{d}}$ & $60.00^{\mathrm{e}}$ \\
\hline 17-Catuaí Vermelho 144 & $203.60^{d}$ & $48.32^{\mathrm{d}}$ & $89.00^{\mathrm{c}}$ \\
\hline 18-Catucaí Amarelo 20/15 & $216.40^{c}$ & $45.96^{\mathrm{d}}$ & $66.00^{\mathrm{e}}$ \\
\hline 19-Catiguá MG 01 & $217.40^{\mathrm{c}}$ & $62.34^{\mathrm{a}}$ & $100.00^{\mathrm{a}}$ \\
\hline $20-\mathrm{H}-419-10-6-2-5-10-1$ & $195.40^{\mathrm{e}}$ & $45.72^{\mathrm{d}}$ & $69.60^{\mathrm{e}}$ \\
\hline 21-IPR104 & $189.40^{\mathrm{e}}$ & $47.08^{\mathrm{d}}$ & $76.20^{\mathrm{d}}$ \\
\hline 22-Sacramento & $192.80^{\mathrm{e}}$ & $54.84^{\mathrm{c}}$ & $76.80^{\mathrm{d}}$ \\
\hline 23-Bourbon Amarelo JCL 10 IAC & $257.80^{\mathrm{a}}$ & $66.34^{\mathrm{a}}$ & $86.00^{\mathrm{c}}$ \\
\hline 24-Pau Brasil & $200.40^{\mathrm{d}}$ & $50.16^{\mathrm{c}}$ & $85.60^{\mathrm{c}}$ \\
\hline $25-\mathrm{H}-419-10-6-2-5-1$ & $188.00^{\mathrm{e}}$ & $47.46^{\mathrm{d}}$ & $84.80^{c}$ \\
\hline
\end{tabular}

Means followed by the same letter do not differ by the Scott Knott test at 5\% probability.

The variability of vegetative characteristics probably occurred because of the combination of genetic effects of each material and the environment (weather conditions, spacing, etc.), indicating the need to interpret these interaction and recommend cultivars for each 
region and management. According to Carvalho et al. (2010), the height and number of plagiotropic branches have strong environmental effects that are greater than those observed for productivity.

The main selection criterion in coffee is productivity (Oliveira et al., 2011). Other agronomic traits related to yield potential have been studied to increase the indirect selection efficiency (Severino et al., 2002; Petek et al., 2008; Pinto et al., 2012).

Two groups were distinguished when analyzing the productivity in the 2009/2010 biennium, highlighting the Catiguá MG 02 and IPR 103 cultivars (Table 3). The Catucaí group, with the exception of Catucaí Vermelho 785/15, also showed high productivity. Paiva et al. (2010), working with genotypes of arabica coffee in Varginha, MG, Brazil, observed higher productivity in the first biennium for Sabiá 398, Catucaí Amarelo 24/137, Acauã, Palma II, and Catucaí Amarelo 20/15, which also showed higher average productivity in this study.

Table 3. Means of productivity of the 2009/2010 and 2011/2012 biennia, average biennial grains retained on the sieve size 16, and moca grains from 25 arabica coffee genotypes in northwestern Rio de Janeiro State, Brazil.

\begin{tabular}{|c|c|c|c|c|c|}
\hline Genotype & $\begin{array}{c}\text { Biennium }^{(1)} 2009 / 2010 \\
\text { (bag/ha) }\end{array}$ & $\begin{array}{c}\text { Biennium 2011/2012 } \\
\text { (bag/ha) }\end{array}$ & $\begin{array}{l}\text { Average biennia } \\
\quad \text { (bag/ha) }\end{array}$ & Sieve size $16(\%)$ & Moca $(\%)$ \\
\hline 1-Catucaí Vermelho 785/15 & $61.79^{\mathrm{bA}}$ & $48.99^{\mathrm{cA}}$ & $55.38^{\mathrm{c}}$ & $82.00^{\mathrm{a}}$ & $16.00^{\mathrm{c}}$ \\
\hline 2-Catucaí Amarelo 2 SL & $89.86^{\mathrm{aA}}$ & $84.37^{\mathrm{bA}}$ & $87.12^{\mathrm{a}}$ & $83.00^{\mathrm{a}}$ & $18.00^{\mathrm{c}}$ \\
\hline 3-IPR & $71.31^{\mathrm{bA}}$ & $67.32^{\mathrm{cA}}$ & $69.31^{\mathrm{b}}$ & $72.00^{\mathrm{b}}$ & $15.00^{c}$ \\
\hline 4-Catiguá MG 02(2) & $115.00^{\mathrm{aA}}$ & $83.85^{\mathrm{bA}}$ & $99.43^{\mathrm{a}}$ & $69.66^{\mathrm{b}}$ & $14.00^{\mathrm{c}}$ \\
\hline 5-IPR 99 & $81.93^{\mathrm{bA}}$ & $64.85^{\mathrm{cA}}$ & $73.39^{b}$ & $87.00^{\mathrm{a}}$ & $14.00^{\mathrm{c}}$ \\
\hline 6-Acauã & $89.58^{\mathrm{aA}}$ & $78.12^{\mathrm{bA}}$ & $83.85^{\mathrm{a}}$ & $67.66^{\mathrm{b}}$ & $25.66^{\mathrm{b}}$ \\
\hline 7-Araponga MG 01 & $71.95^{\mathrm{bA}}$ & $75.52^{\mathrm{bA}}$ & $73.73^{b}$ & $82.33^{\mathrm{a}}$ & $14.00^{\mathrm{c}}$ \\
\hline 8-Palma II & $91.63^{\mathrm{aA}}$ & $85.68^{\mathrm{bA}}$ & $88.65^{\mathrm{a}}$ & $73.00^{\mathrm{b}}$ & $23.00^{\mathrm{b}}$ \\
\hline 9-Sabiá 398 & $97.78^{\mathrm{aA}}$ & $103.52^{\mathrm{aA}}$ & $100.65^{\mathrm{a}}$ & $71.33^{\mathrm{c}}$ & $11.66^{\mathrm{c}}$ \\
\hline 10-IPR 103 & $103.61^{\mathrm{aA}}$ & $90.36^{\mathrm{bA}}$ & $96.99^{\mathrm{a}}$ & $81.66^{\mathrm{a}}$ & $12.66^{\mathrm{c}}$ \\
\hline 11-IPR 100 & $92.50^{\mathrm{aA}}$ & $87.37^{\mathrm{bA}}$ & $89.93^{\mathrm{a}}$ & $82.66^{\mathrm{a}}$ & $17.66^{\mathrm{c}}$ \\
\hline $12-\mathrm{H}-4193-3-3-716-4-1$ & $81.39^{\mathrm{bA}}$ & $77.08^{\mathrm{bA}}$ & $79.24^{\mathrm{b}}$ & $77.33^{\mathrm{a}}$ & $16.33^{\mathrm{c}}$ \\
\hline 13-H-419-10-6-2-12-1 & $84.17^{\mathrm{aA}}$ & $82.94^{\mathrm{bA}}$ & $83.56^{\mathrm{a}}$ & $51.00^{\mathrm{c}}$ & $22.33^{b}$ \\
\hline 14-Catucaí Amarelo 24/137 & $91.11^{\mathrm{aA}}$ & $104.17^{\mathrm{aA}}$ & $97.64^{\mathrm{a}}$ & $78.00^{\mathrm{a}}$ & $14.33^{\mathrm{c}}$ \\
\hline 15 -Iapar $59^{(2)}$ & $87.68^{\mathrm{aA}}$ & $58.85^{\mathrm{cA}}$ & $73.27^{\mathrm{b}}$ & $67.00^{\mathrm{b}}$ & $8.00^{\mathrm{c}}$ \\
\hline 16-Oeiras ${ }^{(2)}$ & $74.44^{\mathrm{bA}}$ & $95.05^{\mathrm{aA}}$ & $84.75^{\mathrm{a}}$ & $65.00^{\mathrm{b}}$ & $15.66^{\mathrm{c}}$ \\
\hline 17-Catuaí Vermelho $144^{(2)}$ & $69.60^{\mathrm{bA}}$ & $90.37^{\mathrm{bA}}$ & $80.01^{\mathrm{b}}$ & $71.33^{\mathrm{b}}$ & $16.66^{\mathrm{c}}$ \\
\hline 18-Catucaí Amarelo 20/15 & $96.94^{\mathrm{aA}}$ & $107.03^{\mathrm{aA}}$ & $101.99^{\mathrm{a}}$ & $72.00^{\mathrm{b}}$ & $11.33^{\mathrm{c}}$ \\
\hline 19-Catiguá MG 01 & $67.08^{\mathrm{bA}}$ & $68.49^{\mathrm{cA}}$ & $67.79^{\mathrm{b}}$ & $55.33^{\mathrm{c}}$ & $31.33^{\mathrm{a}}$ \\
\hline $20-\mathrm{H}-419-10-6-2-5-10-1$ & $89.65^{\mathrm{aA}}$ & $100.00^{\mathrm{aA}}$ & $94.83^{\mathrm{a}}$ & $41.66^{\mathrm{d}}$ & $29.00^{\mathrm{a}}$ \\
\hline 21-IPR104 & $79.82^{\mathrm{bA}}$ & $76.82^{\mathrm{bA}}$ & $78.32^{b}$ & $70.00^{\mathrm{b}}$ & $13.66^{c}$ \\
\hline 22-Sacramento & $74.44^{\mathrm{bA}}$ & $81.78^{\mathrm{bA}}$ & $78.11^{\mathrm{b}}$ & $63.00^{\mathrm{b}}$ & $21.66^{\mathrm{b}}$ \\
\hline 23-Bourbon Amarelo IAC & $53.84^{\mathrm{bA}}$ & $44.27^{\mathrm{cA}}$ & $49.05^{\mathrm{c}}$ & $66.66^{\mathrm{b}}$ & $15.00^{\mathrm{c}}$ \\
\hline 24-Pau Brasil & $80.55^{\mathrm{bA}}$ & $63.28^{\mathrm{cA}}$ & $71.92^{\mathrm{b}}$ & $68.66^{\mathrm{b}}$ & $20.33^{\mathrm{b}}$ \\
\hline $25-\mathrm{H}-419-10-6-2-5-1$ & $86.11^{\mathrm{aA}}$ & $93.49^{\mathrm{aA}}$ & $89.80^{\mathrm{a}}$ & $36.66^{\mathrm{d}}$ & $18.00^{\mathrm{c}}$ \\
\hline
\end{tabular}

Means followed by the same letter in a column and capital letter in a row do not differ by the Scott Knott test at $5 \%$ probability. ${ }^{(1)}$ The $2009 / 2010$ biennium is composed of the sum of the harvests of 2009 and 2010 , and the 2011/2012 biennium is composed of the sum of the harvests of 2011 and 2012. ${ }^{(2)}$ Values of $\operatorname{Pr}>\mathrm{F}=0.0042$, 0.0078, 0.0051, and 0.0053 for Catiguá MG 02, Iapar 59, Catucaí Vermelho 144, and Oeiras, respectively, which contributed to the significance genotype $\mathrm{x}$ biennium interaction.

In the 2011/2012 biennium, 3 groups were distinguished when analyzing the productivity, highlighting Catucaí Amarelo 20/15, Catucaí Amarelo 24/137, Sabiá 398, and H-41910-6-2-5-10-1 (Table 4). The Sabiá 398, Catucaí Amarelo 24/137, Catucaí Amarelo 20/15, H-419-10-6-2-5-10-1, and H-419-10-6-2-5-1 cultivars showed high productivity in the 2 biennia. In split biennia, there were not significant differences between genotypes. However, 
Catiguá MG 02, Iapar 59, Oeiras, and Catucaí Vermelho 144 contributed to the significance of the genotype $\mathrm{x}$ biennium interaction. Paiva et al. (2010) also observed variability for productivity in biennia for various genotypes, including Iapar 59. The same authors observed that there was no significant difference in the productivity of Sabiá 398 in biennia, corroborating the data of this study.

Table 4. Phenotypic correlation between stem diameter, plant height, number of plagiotropic branches, and productivity of 25 arabica coffee genotypes in northwest Rio de Janeiro State, Brazil, in 2011.

\begin{tabular}{lcccc}
\hline & Plant height & Stem diameter & No. of plagiotropic branches & Productivity \\
\hline Plant height & - & $0.5827^{* *}$ & $0.4497^{*}$ & $0.1573^{\mathrm{NS}}$ \\
Stem diameter & & - & $0.1502^{\mathrm{NS}}$ & $-0.0087^{\mathrm{NS}}$ \\
No. of plagiotropic branches & & - & $0.016^{\mathrm{NS}}$ \\
Productivity & & & - \\
\hline
\end{tabular}

*,**Significant at 1 and $5 \%$ probability; $\mathrm{NS}=$ not significant.

Considering the average biennial productivity, 3 groups were distinguished, and $\mathrm{Ca}-$ tucaí Amarelo 20/15, Sabiá 398, Catiguá MG 02, Catucaí Amarelo 24/137, and IPR 103 were highlighted (Table 3). Carvalho et al. (2012) studied the performance of coffee genotypes over 3 biennia in 4 regions of Minas Gerais, Brazil; they found Catucaí Amarelo 24/137, Sabiá 398, and IPR 103 stood out. Over 3 biennia, Paiva et al. (2010) found high average productivity only for Sabiá 398.

Other genotypes in this study also had high average biennial productivity. For example, Catucaí Amarelo 20/15 and Catucaí Amarelo 2 SL, unlike the observations of the previously mentioned authors, demonstrated variable productivity that depended on the planting region. The genotypes that presented a highest average productivity showed a smallest biennial effect, which was characterized by an annual alternation of high and low productivity. Bourbon Amarelo had low productivity; however, Ferreira et al. (2013) observed that Bourbon genotypes exhibited satisfactory productivity and presented genetic variability within the group.

The biennial effect is attributed to the depletion of plant reserves in years of high yield, causing the production of the next year to be low because of the slower growth of plagiotropic branches (DaMatta et al., 2007). Pereira et al. (2011) evaluated the effect of spacing on growth, productivity, and bienniality of coffee and found that there was a reduction in the productive oscillation between harvests with increased spacing between planting lines (2 to $3.5 \mathrm{~m}$ ). However, the same authors concluded that there was an increase in productivity with reduced spacing. Probably, until the fourth harvest, the spacing may have provided good yields for genotypes that were highlighted in the 2 biennia without leading to plant depletion.

Catuai 144 is the genotype that is commonly planted in the region. In the first biennium, it produced 65.22 and $48.85 \%$ less than Catiguá MG 02 and IPR 103, respectively (Table 3 ). In the second biennium, it produced $18.43,15.27,14.55$, and $10.66 \%$ less than Catucaí Amarelo 20/15, Catucaí Amarelo 24/137, Sabiá 398, and H-419-10-6-2-5-10-1, respectively. This suggests that other genotypes, including some that are tolerant to leaf rust such as Sabiá 398 (Paiva et al., 2010), appear to be an option for future plantations in the region. Furthermore, it is noteworthy that Acauã, which showed good yield in relation to average biennia, presents resistance to root-knot nematode (M. exigua) (Carvalho et al., 2008), making it an option for infested areas. This is important because Barbosa et al. (2004) observed that $50 \%$ of the areas of northwest Rio de Janeiro State were infested by M. exigua. 
The sieve coffee classification is one of the criteria to market this product. The importance is given mainly by the performance and the possibility of standardizing the beans for the roasting process. Unevenness result in uneven roasting, causing the occurrence of burnt flavor in the product. Thus, separating coffee beans by size provides a better quality final product, enabling greater uniformity in roasting and greater uniformity in bean color.

The genotypes Catucaí Vermelho 785/15, Catucaí Amarelo 2 SL, IPR 99, Araponga MG 01, IPR 103, IPR 100, H-4193-3-3-716-4-1, and Catucaí Amarelo 24/137 showed the highest values for sieve size 16 (between 78 and 87\%) (Table 3). Pailva et al. (2010) also reported satisfactory results for flat grain in Catucaí Vermelho 785/15 and Catucaí Amarelo 24/137. It is worth noting that Catucaí Amarelo 24/137 also appears in the higher averages productivity group in the 2 biennia, unlike Catucaí Vermelho 785/15, which did not show good productivity in biennia. These observations also corroborate those of Paiva et al. (2010) and Carvalho et al. (2012).

The genotypes Catiguá MG 02, Acauã, Palma II, and Catucaí Amarelo 20/15, which also stood out in biennial productivity, appear in the second group for sieve classification, indicating a satisfactory response to this variable. However, Sabiá 398, which appeared in the third group of averages, showed a good percentage in the sieve classification $(71.33 \%)$. The H-419-10-6-2-5-10-1 and H-419-10-6-2-5-1 genotypes, despite good yield in biennia, did not show satisfactory means for this variable. Further evaluations are needed to confirm the viability of these genotypes for the region.

A large amount of moca grain is indicative of a deficiency at fertilization that is mainly related to genetic and climatic factors (Laviola et al., 2006). Thus, the estimated yield also suffers considerable influence from the amount of fruit that contains moca grains (Vaccarelli et al., 2003). Catiguá MG 01 and H-419-10-6-2-5-10-1 showed the highest percentages of moca beans (Table 4). H-419-10-6-2-5-10-1 also showed a low percentage of sieve size 16, reinforcing the possibility of not being recommended for the region. Except Palma II and $\mathrm{H}$ 419-10-6-2-12-1, genotypes that showed good yields in the two biennia, were in the lower averages group for the moca beans percentage.

Among the genotypes that stood out in productivity and grain quality, Catiguá MG 02, Acauã, Palma II, Sabiá 398, and IPR 100 are derived from crosses involving Timor Hybrid, which has a high yield potential and leaf rust resistance (Bonomo et al., 2004; Oliveira et al., 2011). On the other hand, Catucaí Amarelo 2SL, IPR 103, Catucaí Amarelo 24/137, and Catucaí Amarelo 20/15 are derived from crosses involving Icatú, which also exhibit high productivity and leaf rust resistance (Carvalho et al., 2008). It is worth noting that these genotypes also showed high stability and adaptability over 4 harvests (Rodrigues et al., 2013). However, studies regarding the next harvest and management through pruning should be performed to support the recommendation of these genotypes.

Until the second harvest, positive correlations were observed between vegetative and productivity characteristics (Rodrigues et al., 2012). However, no correlation between productivity and vegetative characteristics were observed for the third harvest, in 2011 (Table 4). There was only a positive correlation between plant height and stem diameter and between plant height and plagiotropic branch number. This illustrates an adjustment of plant architecture that showed no result in the increase of production, probably due to the dense spacing. Reduced spacing may lead to a rapid development in height, as observed by Rena et al. (1998).

Unlike the results obtained in this study, Miranda et al. (2005) evaluated the first 3 
harvests of F5 progenies from crosses between Catuaí Amarelo and Timor Hybrid, and they observed a correlation between productivity and vegetative characteristics. Furthermore, they found that the vegetative attributes that contributed most to the increase in productivity were the plagiotropic branch length, plant height, and stem diameter. However, Severino et al. (2002) found a low magnitude, negative genotypic correlation between productivity and plant height when evaluating the first 3 harvests Catimor lines.

In the fourth harvest, in 2012, negative correlations were observed between plant height and productivity and between stem diameter and productivity (Table 5 ). In the dense spacing used in this study, the plants tended to reach greater height growth because of the increasing competition for light (Melo et al., 2005; Pereira et al., 2011), which may lead to crop intensification and thus reduce the productivity because of a self-shading effect, reducing photosynthetic rates. Furthermore, light is important for the early stages of floral development of arabica coffee (Queiroz-Voltan et al., 2011).

Table 5. Phenotypic correlation between plant height, stem diameter, number of plagiotropic branches, and productivity of 25 arabica coffee genotypes in northwest Rio de Janeiro State, Brazil, in 2012.

\begin{tabular}{lcccc}
\hline & Plant height & Stem diameter & No. of plagiotropic branches & Productivity \\
\hline Plant height & - & $0.5806^{* *}$ & $0.1522^{\mathrm{NS}}$ & $-0.4417^{*}$ \\
Stem diameter & & - & $0.4348^{*}$ & $-0.4788^{*}$ \\
No. of plagiotropic branches & & - & $0.0188^{\mathrm{NS}}$ \\
Productivity & & & - \\
\hline
\end{tabular}

*, **Significant at 1 and $5 \%$ probability; NS $=$ not significant.

Silvarolla et al. (1997) evaluated 57 progenies of Timor Hybrid and found a positive correlation between productivity and vegetative characteristics. In the average of 4 harvests, the authors obtained a high phenotypic correlation between productivity and the plant height and canopy diameter. These observations are different from those of this study, probably because of the genotypes that were used and the experimental and environmental conditions.

The results obtained in this study corroborate those obtained by Martinez et al. (2007), who studied 4 cultivars of arabica coffee in Ervália, MG, Brazil, and observed that, with a spacing of $2.5 \times 0.75 \mathrm{~m}$, the correlation between productivity and plagiotropic branch number was not significant 48 months after planting. Thus, the results indicate that predictable measures for possible interventions by pruning must be taken to avoid a sharp decline in productivity. To avoid the adverse problems caused by crop intensification, crop management techniques, through pruning, are required to rejuvenate and maintain crop productivity, increasing the profitability of the crop (Pereira et al., 2007).

\section{CONCLUSION}

The genotypes Catucaí Amarelo 2 SL, Catiguá MG 02, Acauã, Palma II, Sabiá 398, IPR 103, IPR 100, Catucaí Amarelo 24/137, and Catucaí Amarelo 20/15 showed superior agronomic characteristics and can be recommended for the study region. 


\section{ACKNOWLEDGMENTS}

The authors wish to thank Fundação de Amparo à Pesquisa do Estado do Rio de Janeiro for by granting a master scholarship.

\section{REFERENCES}

Barbosa DHSG, Souza RM and Vieira HD (2010). Field assessment of coffee (Coffea arabica L.) cultivars in Meloidogyne exigua-infested or -free fields in Rio de Janeiro State, Brazil. Crop Prot. 29: 175-177.

Barbosa DHSG, Vieira HD, Souza RM and Silva CP (2004). Levantamento de nematóides de galhas (Meloidogyne spp.) em áreas cafeeiras do Estado do Rio de Janeiro. Nematol. Bras. 28: 43-47.

Barbosa DHSG, Vieira HD, Partelli FL and Souza RM (2006). Estabelecimento de normas DRIS e diagnóstico nutricional do cafeeiro arábica na região noroeste do Estado do Rio de Janeiro. Cienc. Rural 36: 1717-1722.

Bonomo P, Cruz CD, Viana JMS, Pereira AA, et al. (2004). Avaliação de progênies obtidas de cruzamentos de descendentes do Híbrido de Timor com as cultivares Catuaí Vermelho e Catuaí Amarelo. Bragantia 63: 207-219.

Brasil (2003). Instrução Normativa no 8, de 11 de Junho de 2003. Regulamento Técnico de Identidade e de Qualidade para a Classificação do Café Beneficiado Grão Cru. Diário Oficial da República Federativa do Brasil, Ministério da Agricultura, Pecuária e Abastecimento, Brasília, 13 Junho Seção, 22-29.

Carvalho CHS, Fazuoli LC, Carvalho GR and Guerreiro-Filho O (2008). Cultivares de Café Arábica de Porte Baixo. In: Cultivares de Café: Origem, Características e Recomendação (Carvalho CHS, ed.). Embrapa Café, Brasília, 157-226.

Carvalho GR, Botelho CE, Bartholo GF and Pereira AA (2009). Comportamento de progênies F4 x obtidas por cruzamentos de 'Icatú' com 'Catimor'. Cienc. Agrotec. 33: 47-52.

Carvalho AM, Mendes ANG, Carvalho GR and Botelho CE (2010). Correlação entre crescimento e produtividade de cultivares de café em diferentes regiões de Minas Gerais, Brasil. Pesq. Agropec. Bras. 45: 269-275.

Carvalho AM, Mendes ANG, Botelho CE and Oliveira ACB (2012). Desempenho agronômico de cultivares de café resistentes à ferrugem no Estado de Minas Gerais, Brasil. Bragantia 71: 481-487.

Conab (2014). Café Brasil: Série Histórica de Produção. Available at [http://www.conab.gov.br/conabweb/download/ safra/serie_historica_mai2008.xls]. Accessed January 13, 2014.

Cruz CD (2013). Programa Genes (Versão windows): Aplicativos Computacionais em Genética e Estatística. UFV, Viçosa.

Cucolotto M, Pípolo VC, Garbuglio DD and Fonseca Junior NS (2007). Genotype x environment interaction in soybean: evaluation through three methodologies. Crop Breed. Appl. Biot. 7: 270-277.

DaMatta FM, Maestri M and Barros RS (2007). Ecophysiology of coffee growth and production. Braz. J. Plant Physiol. 19: 485-510.

Davis AP, Tosh J, Ruch N and Fay MF (2011). Growing coffee: Psilanthus (Rubiaceae) subsumed on the basis of molecular and morphological data; implications for the size, morphology, distribution and evolutionary history of Coffea Bot. J. Linn. Soc. 167: 357-377.

Ferreira AD, Carvalho GR, Rezende JC and Botelho CE (2013). Desempenho agronômico de seleções de café Bourbon Vermelho e Bourbon Amarelo de diferentes origens. Pesq. Agropec. Bras. 48: 388-394.

International Coffee Organization (2014). Trade Statistics. Available at [http://www.ico.org/trade_statistics.asp] Accessed January 5, 2014.

Laviola BG, Mauri AL, Martinez HEP and Araújo EF (2006). Influência da adubação na formação de grãos moca e no tamanho de grãos de café (Coffea arabica L.). Coffee Sci. 1: 39-42.

Martinez HEP, Augusto HS, Cruz CD and Pedrosa AW (2007). Crescimento vegetativo de cultivares de café (Coffea arabica L.) e sua correlação com a produção em espaçamentos adensados. Acta Sci. Agron. 29: 481-489.

Melo B, Marcuzzo KV, Teodoro REF and Carvalho HP (2005). Avaliação de cultivares de cafeeiro com irrigação, em diferentes espaçamentos na linha de plantio. Rev. Ceres 52: 245-253.

Miranda JM, Perecin D and Pereira AA (2005). Produtividade e resistência à ferrugem do cafeeiro (Hemileia vastatrix Berk. Et. Br.) de progênies F5 de Catuaí Amarelo com o Híbrido de Timor. Cienc. Agrotec. 29: 1195-1200.

Oliveira ACB, Pereira AA, Silva FL and Rezende JC (2011). Prediction of genetic gains from selection in Arabica coffee progenies. Crop Breed. Appl. Biot. 11: 106-113.

Paiva RN, Carvalho CHS, Mendes ANG and Almeida SR (2010). Comportamento agronômico de progênies de cafeeiro (Coffea arabica L.) em Varginha-MG. Coffee Sci. 5: 49-58.

Pereira SP, Guimarães RJ, Bartholo GF and Guimarães PTG (2007). Crescimento vegetativo e produção de cafeeiros 
(Coffea arabica L.) recepados em duas épocas, conduzidos em espaçamentos crescentes. Cienc. Agrotec. 31: 643-649. Pereira SP, Bartholo GF, Baliza DP and Sobreira FM (2011). Crescimento, produtividade e bienalidade do cafeeiro em função do espaçamento de cultivo. Pesq. Agropec. Bras. 46: 152-160.

Petek MR, Sera T, Sera GH and Fonseca ICB (2006). Seleção de progênies de Coffea arabica com resistência simultânea à mancha aureolada e à ferrugem alaranjada. Bragantia 65: 65-73.

Petek MR, Sera T and Fonseca ICB (2008). Predição de valores genéticos aditivos na seleção visando obter cultivares de café mais resistentes à ferrugem. Bragantia 67: 133-140.

Pinto MF, Carvalho GR, Botelho CE and Gonçalves FMA (2012). Eficiência na seleção de progênies de cafeeiro avaliadas em Minas Gerais. Bragantia 71: 1-7.

Queiroz-Voltan RB, Fahl JI and Carelli MLC (2011). Deferenciação floral em cafeeiro arábica (Coffea arabica L.) sob deferentes níveis de radiação. Coffee Sci. 6: 256-268.

Rena AB, Nacif AP, Guimarães PTG and Bartholo GF (1998). Plantios adensados de café: Aspectos morfológicos, ecofisiológicos, fenológicos e agronômicos. Informe Agropec. 19: 61-70.

Rodrigues WP, Vieira HD, Barbosa DHSG and Vittorazzi C (2012). Growth and yield of Coffea arabica L. in Northwest Fluminense: 2nd harvest. Rev. Ceres 59: 809-815.

Rodrigues WP, Vieira HD, Barbosa DHSG and Sousa Filho GR (2013). Adaptability and genotypic stability of Coffea arabica genotypes based on REML/BLUP analysis in Rio de Janeiro State, Brazil. Genet. Mol. Res. 12: 2391-2399.

Severino LS, Sakiyama NS, Pereira AA and Miranda GV (2002). Associações da produtividade com outras características agronômicas de café (Coffea arabica L. "Catimor"). Acta Sci. Agron. 24: 1467-1471.

Silvarolla MB, Guerreiro Filho O, Lima MMA and Fazuoli LC (1997). Avaliação de progênies derivadas do híbrido de Timor com resistência ao agente da ferrugem. Bragantia 56: 47-58.

Vaccarelli VN, Medina Filho HP and Fazuoli LC (2003). Relação entre rendimentos, frutos chochos e sementes tipo moca em diversos híbridos arabusta. Biosc. J. 19: 155-165. 